\title{
GATS AGREEMENT AND ITS EXPECTED IMPACT ON THE IRAQI BANKING SECTOR
}

\author{
Prof. Dr.Thaer Mamood Rasheed Al-ani, Lecturer Ihab Abbas Al-Faisal \\ *College of Administration \& Economics, University of Baghdad
}

DOI: $10.37648 /$ ijrssh.v10i01.053

Received:15 ${ }^{\text {th }}$ November 2019; Accepted:30thDecember, 2019; Published: $29^{\text {th }}$ January, 2020

\begin{abstract}
:
Agreement with the World Bank (GATS) in the international banking environment that operates in the field of human resources management in the outside world. (WTO) This means in all agreements, including the International Trade Agreement (GATS) for banking services. Is it possible to access the financial and banking markets easily? And then out of the state of weakness suffered by Iraqi banks.

With the increasing role of globalization where openness and international competition and its main pillars of the International Monetary Fund (IMF) and the World Bank (WB) and the World Trade Organization (WTO) that general multilateral agreement to regulate the trade of goods and services more comprehensive, and the General Agreement on Trade in Services (GATS) One of the most important international trade agreements, this agreement is the legal framework through which the members of the Organization should deal with the liberalization of the trade in services, especially the financial and banking services sector.

At the international level, the global economy has witnessed many rapid and successive international changes due to the scientific and technological revolution brought about by economic globalization, namely banking globalization, which has made banking activity a global activity through international agreements that have strengthened it. The most important of the Convention (GATS) and its special supplement to banking services, especially within the framework of the sovereignty of market mechanisms and the pursuit of competitiveness, as well as the case at the local level, the activities of the Iraqi banking sector has been affected And significantly the various developments and economic, social and political changes, which reflected on the nature of banks and their activities and services provided to the public.

This agreement comes through the importance of banking services, which ranks second in importance in the (GATS) agreement, which includes several forms of services, most important banking services, which includes a wide range of economic activities at the local and international levels and the provisions relating to the organization of international transactions where banking activity has increased The fastest growing in the world.

For Iraq, the importance of studying the banking sector and the extent of its response and adaptation to the contents of the Convention (GATS) and the need to be structured and development of this sector in line with this agreement is
\end{abstract}


an important area for study and research, as the liberalization of banking services encourages international coordination or consistency starting from standardization And regulations and administrative procedures governing the capital markets and banks in the light of this sector affected by all the provisions of the agreement on banking services and then influence the overall economic activity in Iraq, which requires the importance of focusing on problems related to the structure of the banking sector In addition to the weaknesses of the supervision and supervision bodies, staff and technical expertise to know the potential of this sector in the face of the expected international competition in light of the desired liberalization of international trade in banking services.

\section{MECHANISMS OF INTERNATIONAL TRADE UNDER THE GATS}

Prior to World War II, the world economy witnessed several problems, most notably the existence of trade barriers that hinder the organization of international trade and push for the adoption of protectionist trade policies. The General Agreement on Tariffs and Trade (GATT) in 1947 and through rounds of negotiations The most recent was the Uruguay Round in 1994, a major impetus for the management of the multilateral international trading system, in accordance with the principles to which these countries committed under the GATT, the most important of which is the liberalization of international trade and the establishment of mechanisms for the settlement of disputes and the regulation of international trade on the basis of economic liberalization that emanated from Meh World Trade (WTO) (World Trade Organization) characterized by the diversity and multiplicity of agreements, notably the Convention on the (GATS) (General Agreement on Trade in Services) (Abu Bakr, 2003, p. 102).

\subsection{The GATT development and its basic principles}

The current WTO agreements are a product of the obligations that countries voluntarily negotiated with each other. The United States of America's tariff law, known as Smoot-Hawley, made some people believe that it deepened the Great Depression.

After the war ended, it concluded an international multilateral agreement known as the GATT, which entered into force in January 1948, was based primarily on the liberalization of international trade from all customs and non-tariff barriers to the free movement of goods across borders in order to achieve A competitive trading environment that ensures an optimal allocation of economic resources to achieve the economic well-being of the parties to international trade (Jubouri, 2006, p. 173). International trade movements and the promotion of international capital movements and the associated increase in global investment is the primary objective of this agreement (Al-Hajji, 2001, p. 31), but to achieve these goals requires a legal and functional framework through which the agreements concluded can be enforced, while This is one of the most important reasons that led to its inability to carry out its planned tasks (Abdel Wahab, 2008, p. 28) .Therefore, the GATS agreement is found to have a sound legal basis as a result of the WTO. Approved in the legislative councils of the member states, giving them a solid legal basis, It also includes invisible activities had to find appropriate legislation in the various sectors of services (Cornelius, 1999, P80).

As international trade in services continues to increase, the need for internationally recognized rules is becoming more urgent, especially as the traditional framework for public services has proved increasingly inadequate for the operation of some of the most dynamic and innovative sectors of the economy, thereby fostering the combination of technological and regulatory innovations on the tradeability of services. In addition to changing consumer preferences and thus creating a need for multilateral disciplines (WTO E-Learning, 2014, P75), this agreement has been built with two main pillars, each with a set of commitments:

1. General obligations. Each Member State must respect certain general obligations that apply irrespective of the existence of specific obligations, namely the principles and rules that establish the elements of the obligation of the State acceding to the Convention concerning factors affecting trade in 
services. And automatic to all member sectors, including services (World Trade report, 2007, P194).

2. Specific and specific commitments to negotiate services and service-producing sectors, where members can take measures for some key political concerns, arising from specific commitments relating to market access, national treatment and specific sectors (Abu Harb, 2011, p. 144).
According to the GATS, services comprise multiple and diverse sectors (12 major sectors). In the context of this agreement, these classifications are used for the purposes of negotiation between Member States to determine the type of services to be included in their schedules of obligations and consequently the gradual liberalization of them. And service divisions in accordance with the GATS.

The supply of these services is mainly through four methods of supply, which are defined on the basis of the origin or origin of the service provider. :

\begin{tabular}{|l|c|c|}
\hline $\begin{array}{l}\text { Construction and engineering } \\
\text { services }\end{array}$ & communications Services & Business Services \\
\hline Environment services & Educational services & Distribution Services \\
\hline $\begin{array}{l}\text { Travel and tourism services } \\
\begin{array}{l}\text { Other services not included } \\
\text { elsewhere }\end{array}\end{array}$ & Health services & Finance services \\
\hline
\end{tabular}

Source: Business Guide to the General Agreement on Trade in Services, International Trade Center and Commonwealth Secretariat, 1999, P17.

1- Cross-border supply, this type of supply does not require the physical transport of consumers or suppliers, thus offering or transferring a service from one Member State to another Member State. Outside that country, this type of procurement is shown in banking when individuals are allowed to take out a loan or buy securities from a foreign bank.

2. Consumption abroad is the provision of a service by a service provider in a member country to a service consumer in another country, where consumers are allowed to purchase financial services while traveling abroad. Bank account in a foreign country (Cornelius, 2000, P5).

3- Commercial presence is the offer of service by a service provider from a country through a commercial presence. According to this method of offering services, the service is provided through construction in the country where the service is provided. Service banks can be provided by the establishment of a branch of a foreign bank, in addition this may include the presence of companies or joint ventures or representative offices and others.

It can be said that the two methods above reflect the phenomenon of bank internationalization, which includes two growing trends (Al-Hajjar, 2003, p. 237):

(A) Expansion of the banking business of the concerned State banks through the sale of banking services to non-residents.

B- Establishing banks in the concerned country for branches or affiliated networks abroad to deal with residents or non-residents in the state.

4. Movement of natural persons According to this method, the service is provided by a service provider belonging to a State through the presence of natural persons from that State in another State. Examples of this approach are those who provide banking services in the territory of a foreign country, as well as a bank that opens a branch abroad and allows individuals to be sent to that country (Lal Das, 2009, p. 371).

The methods of supplying banking services were determined on the basis of the location of the service provider (service producer) and the customer (service consumer) taking into account their nationality and nationality (International Trade in Services Statistics Manual, 2010, p. 17). 


\subsection{Trade in banking services in the international and regional economic perspective}

In financial services in the private sector in the Arab world. Mostly on the services provided by the financial sector, so prepare international trade in financial services.

In the field of financial and banking services, and demands your employees in the methods of payment, and for payments that are used in the Internet to a range of financial and banking services and benefit from them (Roy, 2017, p. 10), through a large role in achieving development, its importance lies in several aspects, AlonDiouf, 2014, p. 3):

Private banking financial services that you implement.

Table 2: Growth of the Global Banking Industry for 2008 and 2018

\begin{tabular}{|l|l|l|}
\hline $\mathbf{2 0 1 8}$ & $\mathbf{2 0 0 8}$ & \\
\hline 123.7 & 96.4 & Assets (\$) \\
\hline 0.9 & 1 & Return on Assets (\%) \\
\hline 6.7 & 4.4 & Capital / Assets (\%) \\
\hline
\end{tabular}

Source: Deloitte Center for Financial Services, 2019 Banking and Capital Markets Outlook: Reimagining transformation, 2018,p1.

The rise in the volume and importance of the trade in banking services has led to a shift in gains across a variety of new activities, especially in light of the philosophy of economic and financial liberalization and the transformation of market mechanisms, which helped to build a new international economic system through which banking institutions provide their activities at the market level Many factors in the new international economic order have affected the banking industry, including structural changes in the structure of the international economy (especially during the 1980s and 1990s), which are the result of globalization of markets and finance, as well as The idea of freedom from restrictions, which led to the addition of a new dimension of the intensity of competition from new institutions that were not allowed by law to practice the activities of banks (Mr. Tayel, 2014, p. 161).

The increase in financial flows and international transactions is an essential element in the financial
These services facilitate local transactions, provide local savings mobilization, and extend credit to small enterprises.

In this regard, it should be noted that banking services are the main component of financial services. The international banking system is not only bigger and more profitable but more flexible than ever.According to the credit rating of the top 1000 international banks in 2018, the total assets amounted to $\$ 124$ trillion, The return on assets was $(0.9 \%)$. Similarly, the capital ratio of the first class as a percentage of assets increased to $6.7 \%$, which is much higher when compared to 2008, as shown in the following table: 
particular witnessed a decline in its exports of financial services by $17 \%$, while exports of financial services in Asia decreased by $11 \%$ and in North America by $2 \%$. Financial services exports declined in 2012 due to the turmoil in the financial services sector due to financial instability in the eurozone, which led to further contraction of financial services exports in both Europe and North America (8.42\%) (WTO, 2015, p23).

3- Exports of banking services increased in 2014 compared to 2013 by (5\%), while the rate increased again in 2015 and then decreased until 2016 and 2017 to reach $(8.6 \%)$ and $(8.5 \%)$ respectively, however we
: 2249-4642, p-ISSN: $2454-4671$

note the continuous increase Especially since global banking is an industry worth trillions of dollars with future growth expected and rising, for example, the total international bank lending is approximately (38) trillion dollars, as the new international environment has led to fundamental changes in the way that the organization of international trade In services and because of technological advances increased the capacity of some p services Services have overcome their main characteristics of inability to store and transport (Abdul Ghaffar, 2002, p. 154), and Figure 1 shows the relative importance of exports of banking and other financial services for the period (20042016).

Figure 1. Relative importance of exports of banking and other financial services for the period (2004-2016)

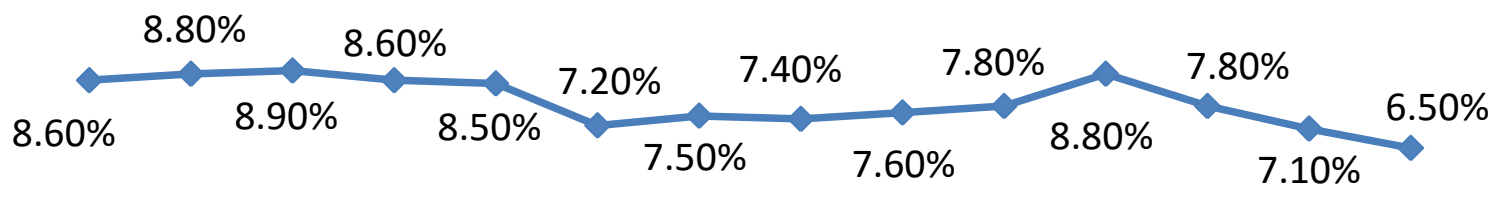

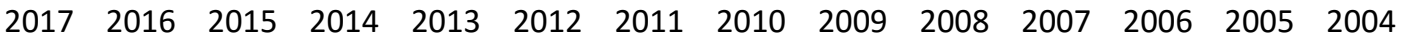

Source:International Trade Center, ITC estimates

\section{ANALYSIS OF THE REALITY OF THE IRAQI BANKING SECTOR}

The banking sector is one of the most important sectors affected and impact on the overall economic activities. Historically through what is known as financial capitalism resulting from the merger of industrial capital with the knowledge capital and then what is known in the modern world as capitalism of information, ie it depends on the power of money and information through openness and Economic competition in the world especially developed ones.

Accordingly, Iraq 's endeavor to build a banking structure and banking services will not be immune from the conditions imposed by international obligations to be adopted and adapted to them within the banking reform and Iraq' s bid to join the (WTO) and thus adhere to the Convention (GATS), and in this regard The banking sector in Iraq should be studied according to:

\subsection{The emergence and development of the Iraqi banking sector}

Historically, banking institutions originated in Iraq at the beginning of the sixth century BC, specifically in Babylon, which originated on money, credit and qualitative benefits, thus Iraq has known banking since ancient times, when Hammurabi identified the financial and banking transactions and fixed by his obelisk known as Hammurabi obelisk.

Iraq witnessed the establishment of commercial banks for the first time in the form known in 1890 as branches of the Ottoman Bank of England took the form of joint-stock companies continued until the First World War, then the number of commercial 
banks three banks in addition to two local banks (Khazraji, 2002, p. 195), and during various stages witnessed the banking sector Al-Iraqi made many changes through structural and organizational changes, represented by the adoption of a trend aimed at reducing the dominance of Arab and foreign banks at times (Hoaish, 2001, p. 458), and allowing the private sector to carry out banking operations at other times due to the economic sanctions witnessed by Iraq in the mid-1990s. For the past (Yahya, 2001, p. 197), and after 2003 resulted in the process of political change new conditions for the trends of the Iraqi economy, the new approach in the management of the economy began to show its features through the announcement of the so-called transition to a market economy, the government deliberately issued a number of legislation and laws Among the most important of these legislation (Shendi, 2011, p. 310 and Saleh, 2008):

1. The issuance of the Central Bank of Iraq Law No. (56) for the year 2004, on which the Central Bank obtained full independence in the management of the monetary authority and the conduct of banking operations, as confirmed by paragraph (2) of Article II of this law (then the Central Bank became an independent authority For the Ministry of Finance).

2- The issuance of the Banking Law No. 94 of 2004, which included new rules for banking business in terms of enhancing economic and financial stability and maintaining the stability of local prices to create a competitive environment based on market mechanisms based on efficiency and profitability as the basis for banking business.

3. Regulation of the relationship between the Central Bank and the banking sector based on the above two laws. Banks are subject to the supervision and control of the Central Bank, starting from the granting of licenses or licenses to liquidation of non-performing banks in accordance with the legal articles contained in the provisions of these laws.

4 - the establishment of the Trade Bank of Iraq in 2004, and increase the capital of Rafidain Bank and Rashid Bank to (500) billion dinars and (400) billion dinars, respectively, based on the decision of the
Economic Committee in 2008, in addition to allowing foreign banks to open branches inside Iraq.

5 - Strengthening the independence of the Central Bank and then control and supervision of banks The Central Bank decided to raise the capital of private banks to (250) billion dinars, equivalent to (220) million dollars within three years from the date of the decision on 18/2/2010 until 30/6/ 2013, with the aim of pushing banks to increase their capital by adopting different methods, the most important of which are merger, contribution or participation with foreign banks.

In an attempt to improve the reality of the banking sector, Iraq has adopted trends for banking liberalization and since the nineties through law No. (12) of 1991, which granted licenses to establish private banks when the concept of privatization and the private sector began to appear clearly during that period, however, this liberalization is partly private With the continuation of the policy of financial restraint, which took the form of setting controls for interest rates and channeling credit through credit plans in addition to imposing legal reserve requirements and ownership of banks until 2003 and with the issuance of the Central Bank of Iraq Law No. (56) for the year 2004 took the following measures (Abdali and 0.2018, p. 396):

1 - Liberalization of interest rates, this measure is one of the most important shifts in the banking business, where the full liberalization of the interest rate on deposits, loans, credits, securities and all other financial instruments, this measure was designed to develop the financial sector in accordance with the latest contemporary methods in addition to abandon the policy of financial restraint .

2 - Cancellation of credit directive, that is, the abolition of the central management of credit and give the task of guidance to the boards of directors of banks, and in order to achieve speed in decisionmaking and to create flexibility was taken interest rates debtor and creditor where enabled banks to expand credit operations and then investment, in addition to enabling banks Increase the reserve expansion necessary to open more banking branches to develop banking density. 
3. Reduce the requirements of the legal reserve in accordance with Article (29) Section VI of the Law of the Central Bank of Iraq, in order to withdraw part of the high liquidity in the Iraqi capital market.

4 - Allow foreign banks to enter the Iraqi banking market by allowing them to work in Iraq, whether in the form of partnerships with private banks or branches or representative offices and in line with the Law on Banks in Iraq No. (94) for the year 2004.

Despite the impact of this climate on the banking labor market and limited on both the structure of banking services provided by Iraqi banks as well as the case of the entry of foreign banks to the Iraqi banking market in the process of banking liberalization adopted after 2003, but what should be noted There is a difference between banking liberalization currently adopted in the framework of reforms adopted by Iraq outside the framework of the Convention (GATS) by virtue of the licenses of the Central Bank and its procedures, where the commitment of banks to implement its directions and with regard to interest rates and aspects of activity and direct credit and others, while the Seen in the context of the commitments made by the member states of the (WTO) it is primarily governed by market mechanisms, which means that even in the commitments, whether horizontal (public) or vertical at the level of each service activity should not be contrary to this mechanism.

\subsection{The nature of banking services provided by banks}

The banking service is the main activity carried out by the Commercial Bank in order to serve its customers, in exchange for a commission earned through the possession of the means and possibilities necessary to implement them. Global banking as indicated by the Convention (GATS), and despite the Iraqi banks provide some modern banking services (such as issuing letters of guarantee and the opening of documentary credits in addition to credit card service), Dima does not suit both in terms of number and quality or procedures and methods adopted in providing with the requirements imposed by economic challenges, especially in light of the adoption of Iraq a market economy approach, as we find a decrease in the number of banking services compared with the world, especially developing countries, not developed, as the number of Banking services (20) service, which is much less than the number referred to in Article (27) of the Iraqi Banking Law, which is more than (50) banking service (Allawi, 2017, p. 283), while banking activity is distinguished from other economic activities must The multiplicity and diversity of banking services, therefore, banks are defined as $\mathrm{m}$ Multi-product institutions (Qureshi, 2005, p. 89).

When comparing the interest income ratio of the banking sector as a whole to the total interest (Table 3 ), we note that the percentage of interest income was high throughout the period (2008-2017) reaching 2017 (98\%), an indicator that banking services Provided in Iraq are mostly traditional services resulting from the granting of credit (loans of various kinds), while the proportion of revenues to banks and non-interest did not exceed the $50 \%$ barrier, which is the income generated from commissions and fees, except for the years $(2009,2012)$ Net non-interest income is almost equal to interest income, which represents income Cash generated from the credit, as the ratio $(53.5 \%)$ in 2009 while the income ratio of non-interest $(46.5 \%)$ of the same year.

Table 3. Interest income (interest income) and non-interest income (interest free income) for the period (20082017)

\begin{tabular}{|l|l|l|l|l|l|}
\hline $\begin{array}{l}(3 / 2) \\
(\%)\end{array}$ & $\begin{array}{l}\text { Total income } \\
(3)\end{array}$ & $\begin{array}{l}\text { Interest income } \\
(2)\end{array}$ & $\begin{array}{l}\text { Interest income } \\
(\mathbf{1})\end{array}$ \\
\hline 21.7 & 78.3 & 1109717 & 239860 & 869857 & 2008 \\
\hline 46.5 & 53.5 & 909913 & 422830 & 487083 & 2009 \\
\hline
\end{tabular}




\begin{tabular}{|l|l|l|l|l|l|}
\hline 31.6 & 68.4 & 884900 & 279407 & 605493 & 2010 \\
\hline 26.6 & 73.4 & 996508 & 265099 & 731409 & 2011 \\
\hline 44.6 & 55.4 & 1831036 & 815940 & 1015096 & 2012 \\
\hline 33.9 & 66.1 & 1731690 & 586962 & 1144728 & 2013 \\
\hline 48.7 & 51.3 & 1436064 & 698781 & 737283 & 2014 \\
\hline 15.9 & 84.1 & 1301483 & 207369 & 1094114 & 2015 \\
\hline 18.3 & 81.7 & 1417498 & 259839 & 1157659 & 2016 \\
\hline 1.1 & 98.9 & 1546788 & 17770 & 1529018 & 2017 \\
\hline
\end{tabular}

Source: Table prepared by the researcher based on the annual statistical bulletin for the years $(2012,2014,2017)$, p. 54. - The first and second columns include net interest income and net interest income.

The most important thing to note from the table is that the rate of income generated from interest peaked in 2017 to reach $98.9 \%$, while the non-interest income rate reached $1.1 \%$. These banks do not have sufficient willingness to borrow from private banks at prevailing interest rates, which would make competition between these banks limited, which indicates the control of government banks on The bulk of the credit granted by the The obedience of the bank is evidenced by the high level of concentration in credit for the largest (5) banks with a difference of (60.25) degrees in 2017 compared to 2016.This comes as a natural result of its network of banking branches spread in Iraq and thus access to its services (CBI, 2017, p. 13 (This can be an indicator of the weak competitive position of Iraqi banks and thus their inability to develop their banking products and products, which means weak competitiveness of local banks to foreign banks and their branches in the event of the implementation of the Convention (GATS), despite the large increase in the number of Iraqi banks) Figure 2) for 2017 however This increase has not been accompanied by an increase in banking services, especially private banks, which are characterized by small capital and which are limited to a small number of banking services, in addition to the geographical spread is still limited and does not exceed the private banks in Baghdad province and provincial centers (Ali, 2018, p. 69) .

Figure 2. Evolution of the banking sector structure in Iraq for the period (2004-2017)

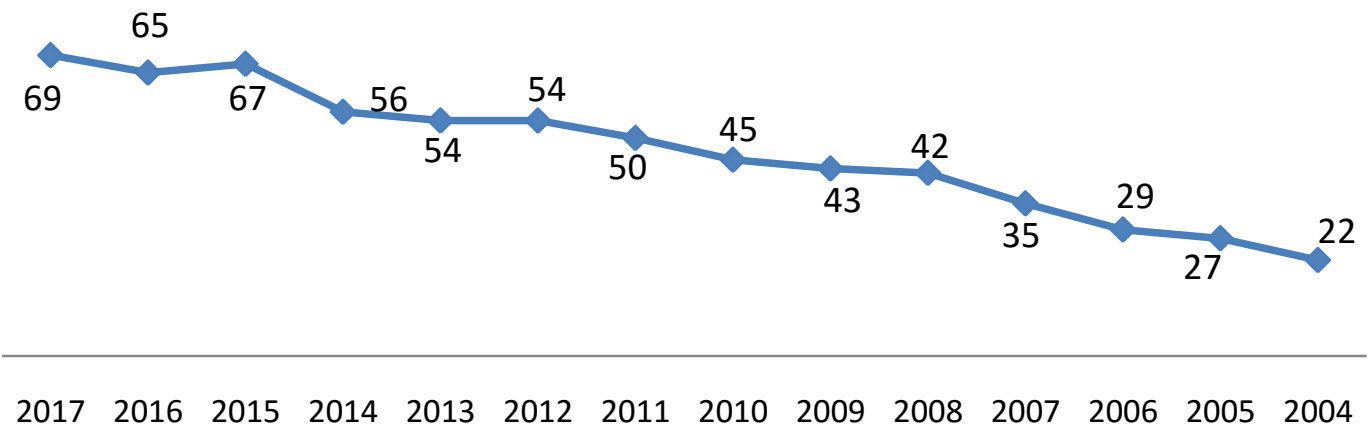

Source: Figure prepared by the researcher based on annual statistical bulletins, years 2004-2017. 
Figure 3: The relative importance of interest income and non-interest income of commercial banks from total revenues

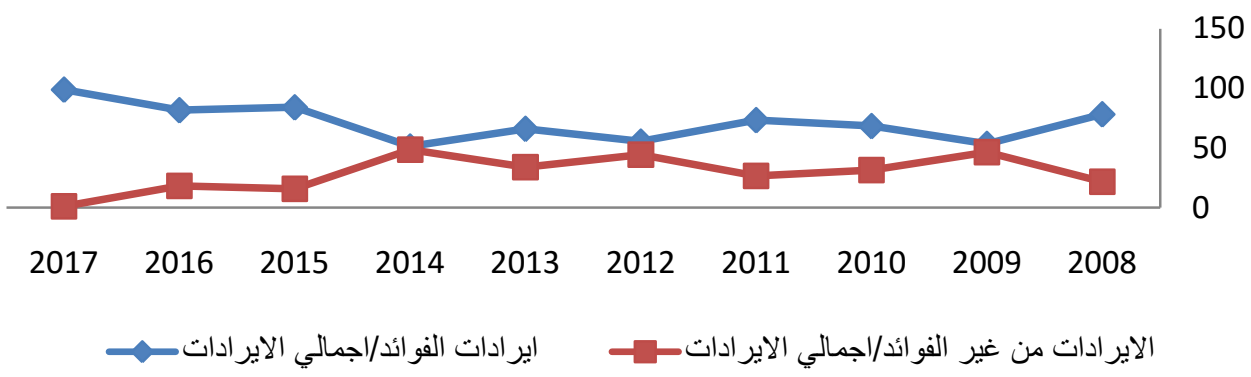

Source: Figure prepared by the researcher based on Table - 3 .

Although the legislative environment in Iraq, represented by the Central Bank of Iraq Law and its instructions and the Law of Iraqi Banks No. (94) for the year 2004 in many of its articles comply with the contents of the Convention (GATS), and therefore there is no conflict between them, but many of these articles came in harmony Exactly with this agreement, perhaps allowing foreign banks or their branches to operate in the banking market is evidence of the policy of banking liberalization adopted by Iraq after 2003, that the state of development of the banking sector can be directly linked to the obligations that can be made by Iraq and in various types of supply in the Convention With GATS Taking into account the implementation of banking reforms that would ensure access to the benefits that can be provided by the agreement, which means that the banking sector and legally is fully consistent with this agreement, but allows the legislative environment more than permitted by the GATS itself and perhaps allow foreign ownership by (100\%) of the banking capital in the joint banks in Iraq is evidence of the harmony of this environment with the agreement that sets this ownership at a minimum (49\%), but this sector is not fully prepared technically and in a way that negatively affects the reality of banking service Provided by banks which is what It can be clarified by relying on a number of indicators, the most important of which are:

\section{1- Total Deposits to GDP Index}

This indicator is known as the financial depth index (Khalaf, 2011, p. 184) or banking (Hamza, 2015, p. 80) .This indicator reflects the ability of banks to attract and then develop capital. It reflects the bank's ability to activate savings. Thus investment-oriented economic development, Figure 4 reflects the financial depth of the period (20042017).

Figure 4 Financial Depth of Period (2004-2017) (\%)

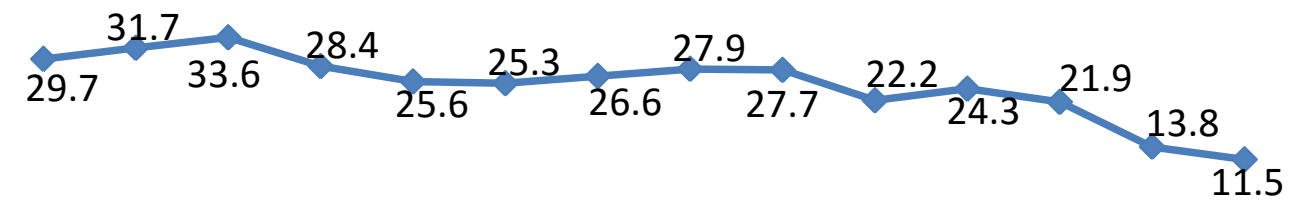

20172016201520142013201220112010200920082007200620052004

Source: Figure prepared by the researcher based on: Central Bank of Iraq, annual statistical bulletins, years (20032017). 
In spite of the increase in the value of this indicator during the period (2004-2017), this increase is considered very weak if compared with the financial depth with a number of countries, for example, but not limited to this percentage in Jordan (115.1\%) in 2004 and In Egypt, this percentage was 82.5\% in 2004 and $95.4 \%$ in 2017 (Arab Monetary Fund, 2017, p. 363). Building a strong financial sector, which indicates that there is a large part of the money supply outside the banks represented by currency in circulation, which means a decrease in banking awareness among the public in addition to weakness Banking services provided by the banks through which deals with individuals, and Figure -5 shows the financial depth in Iraq index compared to a number of countries for the years 2004 and 2017.

Figure 5: Financial Depth in Iraq compared to Number of Countries for the Years (2004 and 2017) (\%)

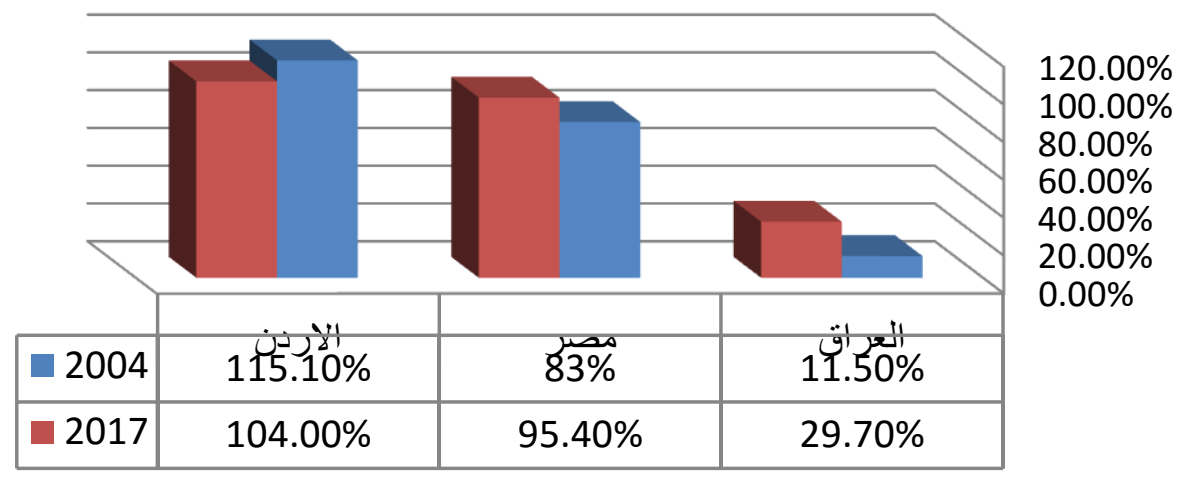

Source: Figure prepared by the researcher based on:

1 - Central Bank of Iraq, the annual economic report, the Directorate General of Statistics and Research, Baghdad, years (2004 and 2017).

2. Arab Monetary Fund, Consolidated Arab Economic Report, Abu Dhabi, years (2005 and 2018).

\section{2 - Index of total bank credit to the private sector to GDP (GDP)}

This index is known as the Bank Depth Index (Financial Depth Report, 2017, p. 14) .This index reflects the size of the financial intermediation of banks and their ability to attract deposits and thus grant loans to investments that achieve the highest possible return. And its relationship to economic activity (Shukri, 2013, p. 186), and Figure 6 reflects the index of banking depth for the period (2004-2017).

Figure 6: Depth of Bank (2004-2017) (\%)

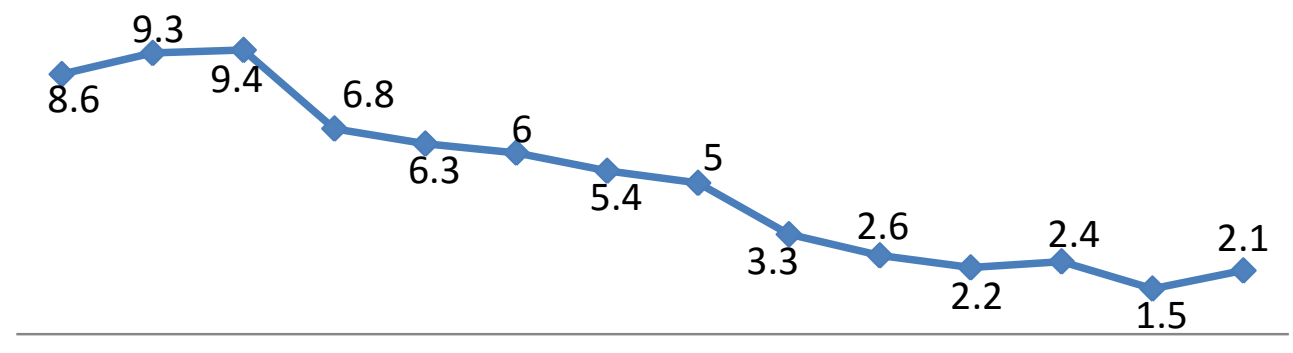

20172016201520142013201220112010200920082007200620052004

Source: Figure prepared by the researcher based on: Central Bank of Iraq, annual statistical bulletins, years (20032017). 
It is noticeable from the figure that the percentage of banking depth witnessed a noticeable increase during the period (2004-2017), which increased from (2.1\%) in 2004 to reach the highest level at (9.4\%) in 2015 and then this percentage decreased to $(8.6 \%)$ year According to international standards, the rate of 5\% is low and therefore a limited contribution to economic activity in order to finance sustainable economic growth (Annual Economic Report, 2008, p. 31). Increase in banking services provided by banks, which means an improvement in financial intermediation as this indicator does not include credit granted by banks By comparing the ratio of total bank credit granted to the private sector to GDP represented by the banking depth with a number of countries, we note that this ratio is considerably low in 2004. This percentage is in Jordan (74.7\%) in 2004 and (75.11\%) in 2017, and in Egypt reached in $2004(54 \%)$ and $(28.5 \%)$ as shown in Figure 7, which means lower level of financial intermediation in the economy due to the lack of development Iraqi Banking Sector.

Figure 7: Banking Depth in Iraq Compared to a Number of Countries for the Years (2004 and 2017) (\%)

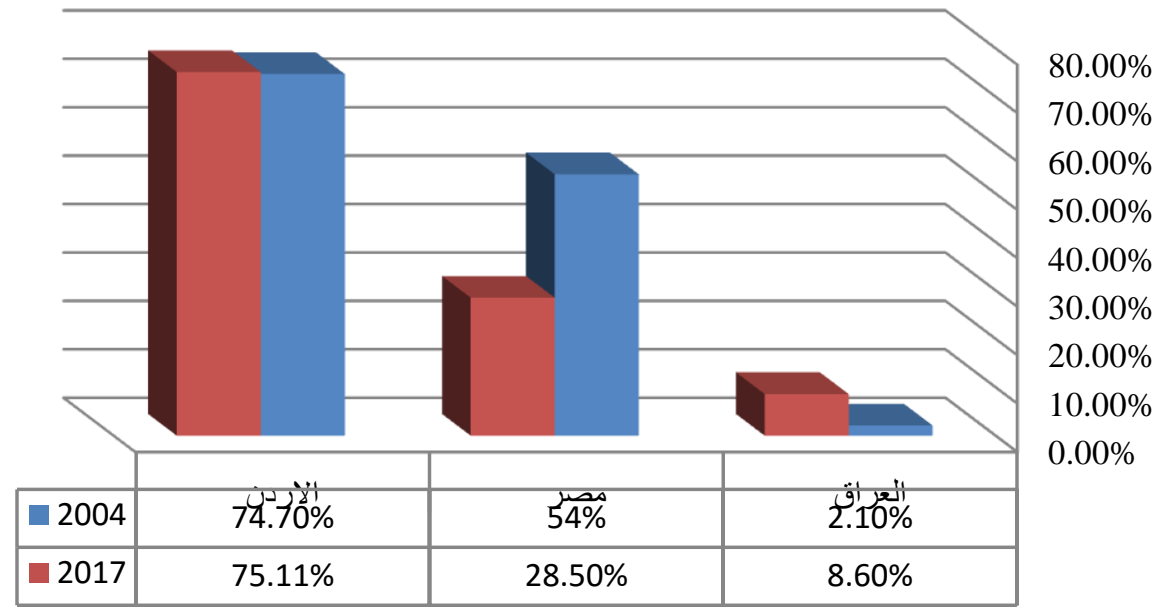

Source: Figure prepared by the researcher based on:

1 - Central Bank of Iraq, the annual economic report, the Directorate General of Statistics and Research, Baghdad, years (2004 and 2017).

2. World Bank, financial sector data.

\section{3 - POPULATION INDEX TO THE NUMBER OF BANK BRANCHES}

It is known as the Banking Density Index, which is measured by the index of the number of branches per (10) thousand inhabitants (Tony, 2003, p. 5). The expansion of the banking sector in the economy, especially as one of the most important components of this index is the number of banking branches spread in the economy, and the increase in banking density means more banking services and therefore higher credit, Figure 8 shows the banking density index for the period (2006-2017). 
Figure 8: Banking Density Index (2006-2017)

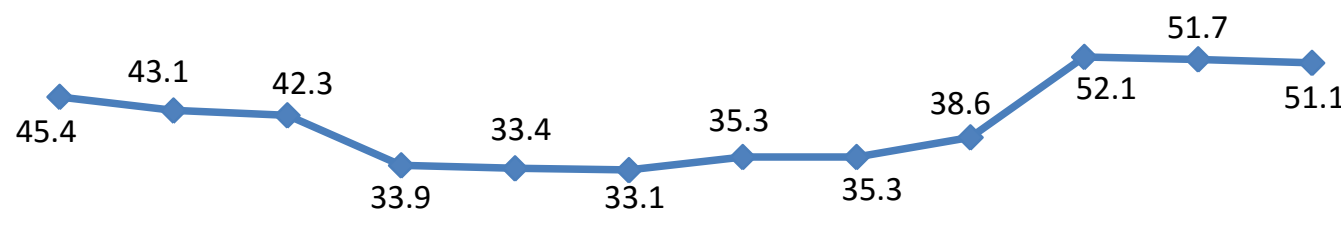

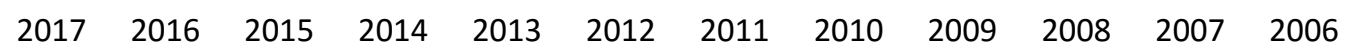

Source: Figure prepared by the researcher based on:

1 - Central Bank of Iraq, the annual statistical bulletin, Directorate General of Statistics and Research, Baghdad, years (2004 and 2017).

\section{World Bank, financial sector data.}

It can be seen from the figure that the banking density reached in 2006 (51) thousand people for each bank branch, while it reached its lowest level in 2012 to reach (33) thousand people in 2012, where the number of banking branches during 2012 reached (944 (branches and the population) The number of banking branches decreased by (151) while the population increased by (327) thousand compared to (542) branches in 2006 and (27697) thousand. Therefore, the index witnessed a decrease during 2017, this percentage is still low when compared with a number of countries, which can be illustrated by Figure 9, which shows the density index Iraq compared to a number of countries (2008 and 2017).

Figure 9: Index of Banking Density in Iraq Compared to Number of Countries for the Years (2008 and 2017)

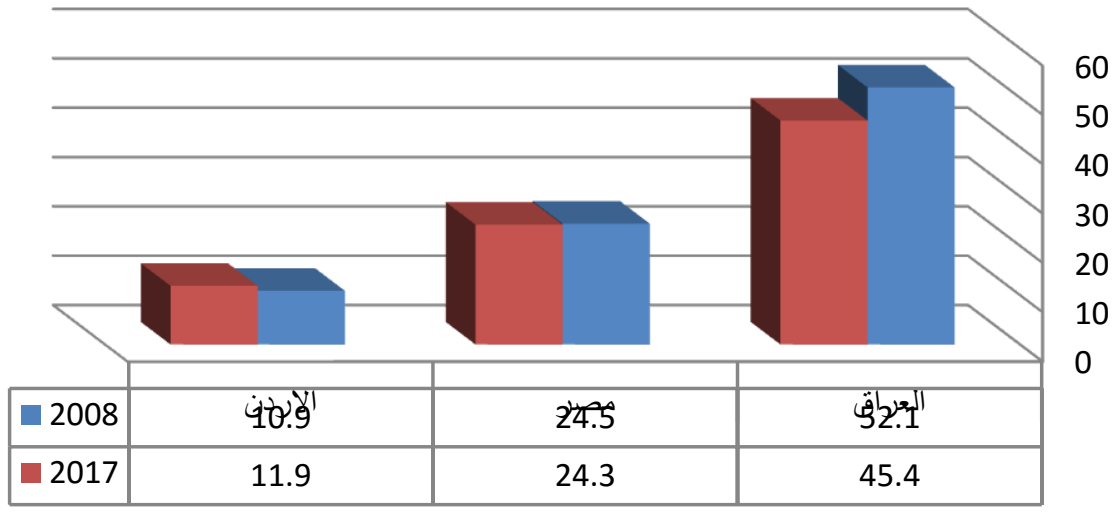

Source: Figure prepared by the researcher based on:

1- Central Bank of Iraq, Annual Statistical Bulletin, General Directorate of Statistics and Research, Baghdad, years (2008 and 2017).

2.Central Bank of Egypt, Annual Report (2008 and 2017). 
3. Central Bank of Jordan, Statistical Bulletins.

4- Association of Banks in Lebanon, http://www.abl.org.lb/en/subPage.aspx?pageid=12342

The figure shows a decrease in the density of banking density in Iraq compared to Egypt and Jordan.In 2017, the banking density in Egypt reached (24) thousand inhabitants per bank branch, while in Jordan it reached (11) thousand people per banking branch.It should be noted that in the States United States The banking density reached (5) thousand people per banking branch, and in the European Union (1500) thousand people per banking branch.

Through the indicators selected above we note that there is a significant weakness suffered by the Iraqi banking sector, especially technically, which reflected negatively on the nature of the banking service provided, which did not witness a marked improvement during the period (2004-2017) remained a traditional banking service excellence, this would To reflect negatively on the advantage of the advantages that can be provided by the GATS agreement, especially in light of the expected competition when joining the (WTO), the banking market did not witness a state of competition in which banks can prepare for the expected entry of foreign banks, although The number of private banks is The number of government banks exceeded the activity of the latter, which is much greater than the activity of private banks. While the remaining $13 \%$ was the share of other government banks in addition to local and foreign private banks, despite the low level of concentration in 2017 compared to 2017 . However, the overall concentration level remains high according to the Herfindahl - Hirschman Index. Used by the Central Bank as this level still exceeds the limits (2000) points, which means a high concentration level in banking assets and therefore the presence of monopoly in the banking sector, which means weak competition, and the high level of concentration simply reflects the lack of adoption of commercial banks Figure 10 shows the level of concentration of assets of the largest (5) banks according to the index (Herfindahl - Hirschman) for the period (2015-2017).

Figure 10 - Concentration level of assets for the largest (5) banks according to the index (Herfindahl -

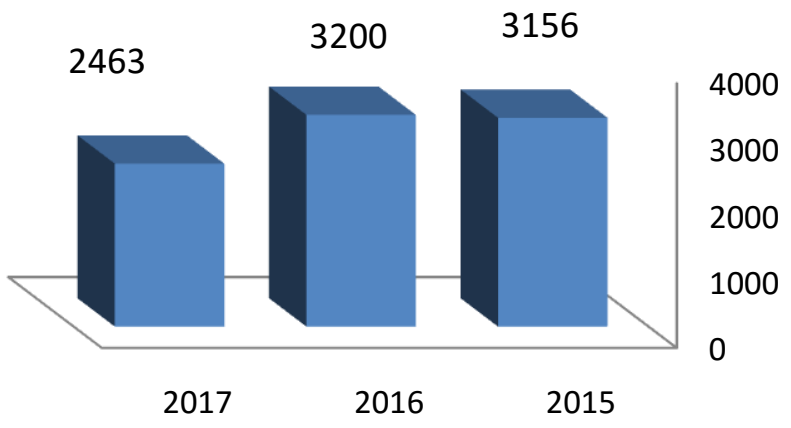

Hirschman) for the period (2015-2017)

Source: Figure prepared by the researcher based on:

Central Bank of Iraq, Annual Report on Financial Stability in Iraq, General Directorate of Statistics and Research, Department of Financial Market Research, Baghdad, years (2016, 2017).

\section{POTENTIAL RISKS TO THE BANKING SECTOR UNDER GATS ENFORCEMENT}

The liberalization of the service sector under the terms of the GATS would bring both opportunities and challenges. As is well known, one of the issues that have been and still is in dispute between developing and developed countries is the issue of liberalizing international trade in services. In its view, liberalization of trade in services will negatively affect the services sector.To find solutions to this dispute, a legal separation was made between the body negotiating issues relating to trade in goods and 
the body negotiating issues related to services trade, which means that negotiations on services trade do not enter into the framework of the GATT. GATT) Among developed and developing countries, it is a basis for determining the meaning of services. Developed countries are of the view that everything that is not a commodity is a service, whereas developing countries believe that the concept of services is limited only to transactions that require the transboundary movement of a service provider and the transboundary movement of consumers. To the transition of production elements to provide this service (Hashad, 2001, p. 118).

Despite the positive effects identified by the GATS on the banking sector, especially with regard to the gains resulting from the transfer of banking technology through advanced behaviors in the areas of accounting and the use of modern banking tools, which is the basis on which the commercial presence of foreign banks, as it achieves technological potential Several advantages of banks, the most important competitive advantage that can be gained by the provision of banking services linked to hightech, which makes these services more quality and satisfy the consumer, as well as the possibility of developing banking skills This is what can bind foreign banks through their commercial presence in the country and through the schedules of commitments that can be made by Iraq in this regard, but there are a number of negative effects are identified, the negative effects that can be generated by the membership of Iraq's accession to (WTO) The commitment to the GATS Agreement is the result of the lack of basic requirements and the necessary means to understand the dimensions of the agreement committed by the member countries, which worked to restructure its banking sector and find the conditions, constraints and limitations towards strengthening the role of banking in it as a fundamental means towards While the Iraqi banking sector, when enforcing the agreement in case of membership of Iraq, faces many negative effects, especially in the short and medium term; it is known that Iraq, like other developing countries, is a net importer of services, which makes the expected negative effects especially large under
Underdevelopment of the banking sector. The desired liberalization process that the banking sector will face may have significant damage that makes it the first recipient of crises as a result of international integration and integration, especially since banks are the main risk carriers in any economic system (Pathak, 2006, P6). As follows:

\subsection{Unequal competition with foreign banks}

The GATS agreement gave foreign banks the freedom to have commercial presence in the banking markets of their host countries through their branches and representative offices to provide various forms of banking services. Therefore, the liberalization process required under this agreement will create a kind of unequal competition with foreign banks. While the banking services provided by the Iraqi banks are still characterized by their traditional and therefore modest compared to the services of foreign banks in addition to low capital, which makes these banks in the face of intense competition at the international level, especially in light of It has its assets compared to foreign banks (Al-Hajjar, 2003, p. 273), which can be seen in Figure 11, which shows the banking assets in Iraq compared to a number of countries for the years (2004 and 2017), as we note the decline in bank assets, which means that there is great potential to face The banking sector is highly competitive if these assets are taken into consideration. This confirms that government banks own the largest part of them, and thus have the largest market share compared to private banks, which are characterized by low volume of assets and then a lower market share. Wa Private banks are a monopolistic competition as a result (Battal and Al-Dulaimi, 2018, p. 329). On the other hand, many studies have shown that the large presence of foreign banks depends mainly on profit margins and costs for local banks, as they tend to achieve higher profits than local banks in developing countries. While their profitability is lower in developed countries with advanced banking sectors (Uiboupin, 2004, P11), on this basis, increased competition will result in the exit of a large number of local banks from the market as it will open to the suppliers of banking services from foreign banks to compete between the sector. Banking The local, which is no longer enjoying any form of support, is 


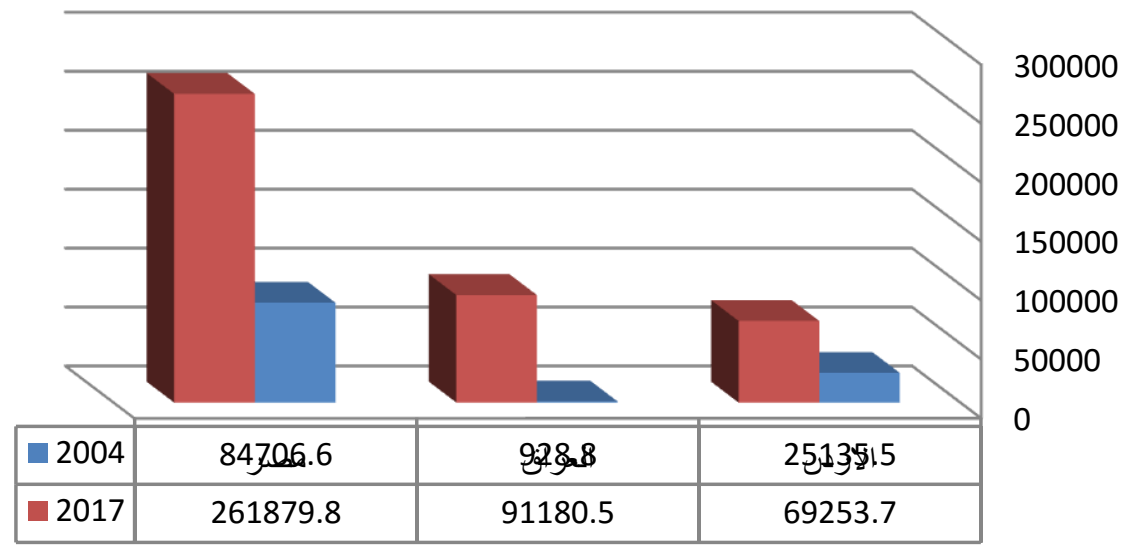

Source: Figure prepared by the researcher based on: 1 - Central Bank of Iraq, the annual statistical bulletin, Directorate General of Statistics and Research, Baghdad, (2004 and 2017).

2- Arab Monetary Fund, the unified Arab economic report, Abu Dhabi, years (2006 and 2018).

\section{2 the risk of capital flow and volatility}

Article 11 of the GATS prohibits members from restricting payments and transfers of capital transactions that fall within their defined obligations. Likewise, any restrictions on capital transactions must be in accordance with the access conditions recorded by the member in his schedule of obligations (Adlung\&Mattoo). Therefore, the commercial presence of foreign banks will enable them to transfer capital according to their own interests. Therefore, liberalization of the trade in banking services requires careful preparation (Kono\& Others, 1997, P23). The free movement of capital has left many negative effects in astig Monetary authorities often lose their ability to formulate the appropriate monetary policy, specifically exchange rate policies and price stability, in addition to the large financial shocks resulting from the sudden exit of capital (Abdul Aziz, 2011, p. 117), and therefore the GATS guarantees Restrictions on the movement of capital do not undermine the free trade of other members, in accordance with the specific commitment (Pasini, 2011, P11), and the positive effects already mentioned by the banking sector gains such as more competition and more efficiency in the banking sector. Share with friends: More services at lower prices, as well as transfer of knowledge, technology and skills such as appropriate credit risk management practices and pressure on local authorities to provide a better institutional framework for bank supervision, these effects can occur if banking services are provided through the commercial presence of foreign banks in The domestic banking market, however, is not the case in cross-border supply as the positive effects cannot be expected, and the entry of foreign banks can itself be detrimental if they start working in a weak domestic banking system, as foreign competition in such situations This could trigger a banking crisis because low margins of local banks can make them more vulnerable to loan losses, and local banks may respond to increased competition by taking excessive risks. Moreover, there may be a risk that foreign banks encourage capital flight and withdraw quickly From foreign markets dominating the most profitable market segments, leaving local banks more risky projects, making the domestic financial system more 
vulnerable Therefore, we find that the withdrawal of foreign banks during economic crises, especially crises that can be exposed to their home countries, is possible in host countries characterized by weak regulatory systems and regulatory legislation (Zarrouk et al., 2009, p. 34). Foreign banks are suddenly transferring funds from one market to another because they see changes in risk-adjusted returns (Dobson, 2008, P298), and many developing countries have limited foreign ownership in their domestic banks in an attempt to avoid the effects.

\subsection{Impact on the economic policies of the State}

Frequently, the question is raised about GATS members 'obligations in relation to national policy objectives, although GATS commitments are not intended to weaken governments' ability to pursue sound macroeconomic and regulatory policies, (GATS provides considerable freedom to achieve domestic economic objectives, but the Convention emphasizes in paragraph 2 (a), that precautionary or precautionary measures that are inconsistent with other provisions of the GATS should not be used as a means of avoiding obligations under the Convention P292), which means that the policies of foreign banks can be influenced The economic policies of the state, including monetary policy, credit policy and foreign exchange control policy, as well as the possibility of blocking some national industries supported by local banks (Hashad, 2001, p. 343), which means the conflict between the private interest of foreign banks and the public interest of the state However, they operate in accordance with the policies of the parent bank and this may entail contradictions with the economic policies of the State in which the branches of these banks are located (Qabil, 2007, p. M For example, it is very difficult to accept conditions that set a ceiling for bank lending. Entry and operation of branches of foreign banks in an environment of liberalization from various forms of financial restrictions and open to the outside may have a negative impact on monetary and credit policies. The host country, especially since these banks are highly subject to the policies of the parent banks, whose objectives are certain to differ from those of the economic policies of the host country (al-Afouri, 2000 , p. 201). To retain sovereignty over local regulations under the GATS and therefore fear that gradual liberalization under this agreement may undermine the authority of the government at various levels to define and pursue its national interests and policy objectives and force it to liberalize its service sectors (Chanda, 2002, P12); Especially since the expected negative effects are mainly on the possibility of controlling large investors or speculators at the international level monetary policy, which requires the government to take measures that can preserve the government's great ability to control and control the local markets and benefit Period Available to it during the gradual liberalization to strengthen its banking sector in order to face the new international economic developments, and in this regard it must be noted that the Central Bank of Iraq after 2003 has adopted a set of measures related to this aspect and perhaps the most important use of automatic control through regulatory and administrative regulations in order to make The banking sector operates according to a flexible and efficient system capable of adapting to financial liberalization policies and responding to international economic and banking developments.

\subsection{Burdens on the balance of payments}

The liberalization of the trade in banking services is expected to lead to a balance of payments deficit. This is due to the fact that the state that does not have a comparative advantage in the services sector will resort to importing services from abroad. A burden on the debtor side of the unforeseen trade balance of importing services while there is no increase in the credit side of exporting services, resulting in a permanent balance of payments deficit (Amara, 2007, p. 282). Payable The financial account is one of the important sub accounts because it refers to financial transactions related to direct investment in addition to portfolio investment and other investments (ESCWA, 2004 , p. 3), and during the period (2005-2017) The net financial account recorded a deficit in 2009 and 2010, while the period (2011-2016) saw a surplus in the net financial account, while the net financial account in 2017 recorded a surplus. \$ (5837.8) million, note that these developments in the net sense $\mathrm{B}$ financial but comes as a result of developments in both the financial assets and liabilities for this 
account, as shown in Table -4 showing the net

financial account for the period (2005-2017)

Table 4. Net financial account for the period (2005-2017) (US \$ million)

\begin{tabular}{|l|l|l|l|}
\hline Net financial account & Year & Net financial account & Year \\
\hline 25078.7 & 2012 & -1434.1 & 2005 \\
\hline-5105.4 & 2013 & -9868.7 & 2006 \\
\hline-15462.7 & 2014 & -16616.4 & 2007 \\
\hline-18445.0 & 2015 & -21588.6 & 2008 \\
\hline-2775.2 & 2016 & 7241.3 & 2009 \\
\hline 5837.8 & 2017 & 1422.9 & 2010 \\
\hline & & -22815.4 & 2011 \\
\hline
\end{tabular}

Source: Central Bank of Iraq, Annual Statistical Bulletin, General Directorate of Statistics and Research, Baghdad, years (2005-2017).

The foregoing, although the GATS agreement does not constitute a conflict with the policies adopted in Iraq, especially in light of the liberalization policies adopted after 2003, and with the statement of negative effects can be said that in light of the challenges posed by banking globalization, it depends mainly On the efforts to be made that would maximize the positive impact and low negative impact and in a manner that ensures adaptation to the contents of the Agreement (GATS), through real reforms that must be adopted in the framework of the development of the Iraqi banking sector and to enhance the efficiency and durability of this sector, while negotiations With the WTO effect $\mathrm{k}$ This means that the desired liberalization of the banking sector in front of foreign competition can lead to the imbalance of payments due to the transfer of foreign banks or a large part of them abroad, which leads to the liberalization of the banking sector. Depriving Iraq of financial resources to finance national development plans.

\section{CONCLUSIONS:}

Services are now the most dynamic part of international trade. Since 1980, international trade in services has grown rapidly. Services are the largest component of both developed and developing economies and constitute major inputs into the production of most "tangible" goods. Services have been a key feature of trade agreements. It is oriented towards deeper and comprehensive integration and is characterized by a strong regulatory focus so that the expansion of international trade in services, including banking services, has become of great importance in light of technological progress and the opening of new international trade outlets, where the importance of banking services to the economy. In many respects, it is the main component of financial services. The international banking system is not only bigger and more profitable but more flexible than ever. The most important outcome of the Uruguay Round was the establishment of the World Trade Organization and the emergence of several agreements that went beyond the commodity sector. To include the services sector through the General Agreement on Trade in Services (GATS), especially since liberalization outside the framework of the GATS Agreement differs from it under this agreement, the former is restricted by the laws and regulations of banks and the Central Bank, while the latter is governed by market mechanisms, especially under the commitments made by Members (WTO). In our study of banking services provided by Iraqi banks we found that most of the services provided are traditional functions compared to the basket of international banking services as indicated by the Convention (GATS), and despite the Iraqi banks to provide some modern banking services (such as issuing letters of guarantee and opening letters of credit In addition to the credit card service, however, it is not commensurate in terms of number, quality, 
procedures and methods adopted in providing it with the requirements of the economic challenges, which has been proved in practice. The banking sector is characterized in a way Abu another stereotypical or traditional through the use of traditional means of banking, especially if we take into account the government banks, which ranks first in the banking sector, and although the legal environment in Iraq is largely consistent with the implications of the Convention (GATS) Especially in light of the laws and instructions allow foreign banks to be present in the Iraqi banking market as well as allow foreign ownership and by (100\%) in the joint banks, the banking sector is not fully prepared technically to face the negative effects expected to occur under The current situation, as the banking services provided are traditional, as well as the high degree of concentration of banking for the benefit of government banks and at the expense of private banks, which means lack of competition between them and therefore in order to face the expected negative effects, it is necessary to work on restructuring the banking sector and in a manner that ensures adaptation to The restructuring of banks is a natural consequence of the economic developments in the banking arena at the international level and in a way that drives local banking institutions to develop programs and policies for banking reform. Their concern is the trend towards banking integration and adoption of the concept of the bank Comprehensive. Accreditation is necessary to improve performance efficiency, especially as it is a key entry point to ensure efficiency in performance.

\section{SOURCES:}

1- Safia Ahmed Abubakr, Impact of the General Agreement on Trade in Services on the Arab Insurance Market, Second Arab Forum on Marketing in the Arab World Opportunities and Challenges, Doha, 6-8 October 2003

3 - Abdul Razzaq Hamad Hussein al-Jubouri, a study of the implications of the World Trade Organization (WTO) on the trade of Arab agricultural commodities, Tikrit Journal of Administrative and Economic Sciences, Issue (4), University of Tikrit, 2006.
4- Mohammad Omar Al-Hajji, The Reality of GATT, Dar Al-Maktabi, Damascus, 2001.

5 - Al-Fatih al-Babi Abdel Wahab, Sudan Confronting economic globalization through regional blocs, International Company, Cairo, 2008.

8- Othman Abu Harb, International Economy, Osama Publishing House, Amman, 2011.

11- Bassam Hajjar, International Economic Relations, Glory of the University Foundation for Studies and Publishing, Beirut, 2003.

12- Bhajerath Lal Das, WTO Guide to the General Framework of International Trade, Arabization of Reza Abdulsalam, Dar Al-Marikh, Riyadh, 2009.

13- Directory of Statistics of International Trade in Services, Economic and Social Affairs, United Nations, New York, 2010.

15. UNCTAD, United Nations Conference on Trade and Development, Impact of Access to Financial Services on Development, including Highlighting the Impact of Remittances: Economic Empowerment of Women and Youth, United Nations, Geneva, 2014.

17- Mustafa Kamal El Sayed Tayel, Banking Industry and Economic Globalization, University House, Alexandria, 2014.

22- Essam Rashid Hwaish, The Development of the Iraqi Banking System and Future Prospects, Al-Ghad Banks, Union of Arab Banks, Beirut, 2001.

23- WidadYounisYahya, Critical Theory (Theories, Institutions, Policies), Ministry of Higher Education and Scientific Research, Mustansiriya University, 2001.

24 - AdibQasimShendi, the Iraqi economy .... Where ?, Talents House for printing, Najaf, 2011.

25- Appearance of Mohammed Saleh, Monetary Policy of the Central Bank of Iraq and the Requirements of Stability and Economic Growth, Central Bank of Iraq, Baghdad, 2008.

26- Saad Abdul Najem Al-Abdali and Hamid TalebFadhil, Analysis of Financial Emancipation 
Indicators in Iraq for the Period (2015-1990), Journal of Economic and Administrative Sciences, Vol.

27- Sima Mohsen Allawi, activating the role of commercial banks in promoting domestic and foreign investment in Iraq for the period (2003-2013), Journal of Baghdad College of Economic Sciences, No. (53), Baghdad College of Economic Sciences, 2017.

28- Mohammed JamouiKoraichi, Performance Evaluation of Banking Institutions: A Case Study of a Group of Algerian Banks During the Period 19942000, Journal of the Researcher, Issue No. 3, Faculty of Law and Economic Sciences, University of Ouargla, Algeria, 2005.

29- Central Bank of Iraq, Financial Stability Report, Monetary and Financial Stability Section, Baghdad, 2017.

30- Ahmed Abrihi Ali, banks, credit and financial depth between Iraq and the international experience, the Central Bank of Iraq, Baghdad, 2018.

31- Ammar Hamad Khalaf, Measuring the Impact of the Development of the Banking System on Economic Growth in Iraq, Journal of Economic and Administrative Sciences, Vol. 17, No. 64, College of Business and Economics, Baghdad University, 2011.

32- Hassan Karim Hamza, The Financing Role of Iraqi Banks in Achieving Economic Growth, AlGhari Journal of Economic and Administrative Sciences, Vol. 10, No. 32, Faculty of Administration and Economics, University of Kufa, 2015.

33.Arab Monetary Fund, Consolidated Arab Economic Report, Abu Dhabi, 2018.

34- Central Bank of Iraq, Annual Report on Financial Stability in Iraq, General Directorate of Statistics and Research, Capital Market Research Department, Baghdad, 2017.

35- Abdul Azim Abdul Wahed Al-Shukri, Banking Reform in Iraq: Reality and Requirements, AlQadisiyah Journal for Administrative and Economic Sciences, Vol. 15, No. 1, College of Administration and Economics, University of Qadisiyah, 2013.
36- Naji Al-Tony, Banking Reform, Development Bridge Publications, Vol. 2, No. 17, Arab Planning Institute, Kuwait, 2003.

37- Central Bank of Iraq, Annual Report on Financial Stability in Iraq, General Directorate of Statistics and Research, Financial Market Research Department, Baghdad, 2016.

38- Nabil Hashad, Mergers and Acquisitions of Banks in Egypt: Opportunities and Precautions, Working Paper No. (79), Egyptian Center for Economic Studies, Cairo, 2003.

40- Ahmed Hussein Battal and Faisal Ghazi Faisal Al-Dulaimi, Using Hirvindal-Hirschman Index to Measure Competition among Banks Operating in the Iraqi Banking Sector for the Period (2011-2016), Tikrit Journal for Administrative and Economic Sciences, Vol. University of Tikrit, 2018.

44- Taiba Abdel Aziz, The Impact of Financial Openness on Economic Growth, Case Study of Algeria during the Period (1990-2009), Arab Economic Research Journal, Issues (55-56), Center for Arab Unity Studies, Beirut, 2011.

48- Mohammed SafwatQabil, Effects of Financial Services Liberalization on Islamic Banks, 14th Annual Scientific Conference of Islamic Financial Institutions (Milestones of Reality and Future Prospects), Vol. 5, Dubai Chamber of Commerce and Industry, Dubai, 2005.

49- Abdel Wahed El Afoury, Globalization and Challenges and Opportunities, Madbouly Library, Cairo, 1999.

51- Rania Mahmoud Abdel Aziz Emara, Liberalization of International Trade in accordance with the GATS Agreement in the Field of Services (GATS), Dar Al Fikr University, Alexandria, 2007.

52. ESCWA, Economic and Social Commission for Western Asia, Foreign Trade in Services (Sultanate of Oman), International Trade in Services Statistics Symposium, Beirut, 2004.

2- Paul R. Krugman \& Others, International Economics (Theory \& Policy), Ninth Edition, 2012. 
6- Peter K. Cornelius, Trade in Financial Services, Capital Flows, and the Value-at-Risk of Countries, Development Discussion Papers, Development Discussion Paper, Harvard Institute for International Development, No. 715, Harvard University, July 1999.

7- WTO E-Learning, Trade in Services in the WTO, 2014.

9- Business Guide to the General Agreement on Trade in Services, International Trade Center and Commonwealth Secretariat, 1999.

10- Peter K. Cornelius, Trade in financial services, capital flows, and the value-at risk of countries, Leibniz Information Centre for Economics, Working Paper, Research Notes, No. 00-2, EconStor, 2000.

14- Erivaldo Alfredo Gomes, Trade in Financial Services: Major References in International Agreements, THE INSTITUTE OF BRAZILIAN ISSUES, THE GEORGE WASHINGTON UNIVERSITY, Washington, 2008.

14- Martin Roy, The Contribution of Services Trade Policies to Connectivity in The Context of Aid for Trade, Staff Working Paper, Economic Research and Statistics Division, World Trade Organization, 2017. 16- Deloitte Center for Financial Services, 2019 Banking and Capital Markets Outlook: Reimagining transformation, 2018.

18- MarijaLindemane, Country's strategy in export of financial services, Procedia Social and Behavioral Sciences, Vol (24), 7th International Strategic Management Conference, Elsevier Ltd, 2011.

19- WTO, International Trade Statistics, Department of International Trade Statistics, Geneva, 2015.

39- Shubhangi Pathak, Liberalization Of Financial Services Under The WTO, India, 2006:http://www.igidr.ac.in/conf/money/mfc_08/Lib eralization_of_Financial_Services. \%20Subhangi\%20Pahak.pdf..

41- JanekUiboupin, EFFECTS OF FOREIGN BANKS ENTRY ON BANK PERFORMANCE IN THE CEE COUNTRIES, Tartu University Press, Tartu, 2004.

42- Rudolf Adlung\&AadityaMattoo, The GATS, A Handbook of International Trade in Services, Oxford University Press, New York, 2008
43- MasamichiKono, Patrick Low, MukelaLuanga, AadityaMattoo, MaikaOshikawa, and LudgerSchuknecht, Opening Markets In Financial Services And The Role Of The GATS, WTO, 1997..

45- Federico LupoPasini, The International Regulatory Regime on Capital Flows, ADBI Working Paper Series, No. 338, Asian Development Bank Institute, Tokyo, 2011

46- Roland Beck, The Volatility of Capital Flows to Emerging Markets and Financial Services Trade, CFS Working Paper, No.11, Center for Financial Studies, Germany, 2000

47- Wendy Dobson, Financial Services and International Trade Agreements: The Development Dimension, , A Handbook of International Trade in Services, Oxford University Press, New York, 2008.

50- RupaChanda, GATS and its implications for developing countries: Key issues and concerns, DESA Discussion Paper, No. 25, United Nations, New York, 2002. 